\title{
Evaluation of pulmonary involvement in systemic rheumatic diseases with high resolution computed tomography and pulmonary function test: A single-center experience
}

\author{
Ahmet Cemal \\ PAZARLI $^{1}$ (ID) \\ Halil ibrahim YAKAR ${ }^{1}$ (ID) \\ Handan INÖNÜ \\ KÖSEOĞLU ${ }^{\mathbf{1}}$ (ID) \\ Ruken YÜKSEKKAYA \\ ÇELIKYAY ${ }^{2}(I D)$ \\ Timur EKiZ ${ }^{3}$ (ID)
}

${ }^{1}$ Department of Chest Diseases, Gaziosmanpaşa University Faculty of Medicine, Tokat, Turkey

${ }^{1}$ Gaziosmanpaşa Üniversitesi Tıp Fakültesi, Gögüs Hastalıkları Anabilim Dalı, Tokat, Türkiye

2 Department of Radiology, Gaziosmanpaşa University Faculty of Medicine, Tokat, Turkey

${ }^{2}$ Gaziosmanpaşa Üniversitesi Tıp Fakültesi, Radyoloji Anabilim Dalı, Tokat, Türkiye

${ }^{3}$ Unit of Physical and Rehabilitation Medicine, Dermancan Medical Center, Adana, Turkey

${ }^{3}$ Dermancan Tip Merkezi, Fizik Tedavi ve Rehabilitasyon Birimi, Adana, Türkiye
Cite this article as: Pazarlı AC, Yakar Hi, Inönü Köseoğlu H, Yüksekkaya Çelikyay R, Ekiz T. Evaluation of pulmonary involvement in systemic rheumatic diseases with high resolution computed tomography and pulmonary function test: a single-center experience. Tuberk Toraks 2021;69(2):125-132.

\section{Yazışma Adresi (Address for Correspondence)}

\section{Dr. Ahmet Cemal PAZARLI}

Gaziosmanpaşa Üniversitesi Tıp Fakültesi,

Göğüs Hastalıkları Anabilim Dalı,

TOKAT - TÜRKIYE

e-mail: dracp60@gmail.com

\footnotetext{
CCopyright 2021 by Tuberculosis and Thorax.
}

Available on-line at www.tuberktoraks.org.com

\section{ABSTRACT}

Evaluation of pulmonary involvement in systemic rheumatic diseases with high resolution computed tomography and pulmonary function test: $\mathrm{A}$ single-center experience

Introduction: The objective of this study was to investigate the clinical and radiological features and pulmonary function tests (PFTS) in patients with the pulmonary involvement of systemic rheumatic diseases (SRDs).

Materials and Methods: This study was conducted as a retrospective and single-center study. Patients diagnosed with an SRD and admitted/referred to the department of chest diseases of our hospital between January 2015 and June 2019 were enrolled. All patients were evaluated using High Resolution Computed Tomography (HRCT) and PFT.

Results: This study included 68 patients (15 males, 53 females) with a mean age of $62.38 \pm 12.4$ years. Forty-one $(60.2 \%)$ patients had diagnosis of rheumatoid arthritis (RA), $10(14.7 \%)$ patients had sjögren's syndrome (SS), 8 $(11.7 \%)$ patients had systemic lupus erythematosus (SLE), 6 (8.8\%) patients had systemic sclerosis (SSC), and $3(4.4 \%)$ patients had mixed connective tissue disease (MCTD). While RA, SLE, MCTD patients were more commonly 
symptomatic, most of the SS patients were asymptomatic. Overall, 30 (44.1\%) patients had normal PFT. Although 30 (\% 44.1 ) patients were asymptomatic and $30(\% 44.1)$ patients had normal PFTs, at least one imaging finding was found in all patients according to HRCT imaging. "Bronchiectasis" was the most common HRCT finding in RA, followed by "chronic fibrotic changes" and "peribronchial thickening". "Chronic fibrotic changes" and "peribronchial thickening" were the most common changes in SS. Similarly, "peribronchial thickening" was the most common radiologic finding in SLE. As for SSc, "chronic fibrotic changes", "interlobular septal thickening", and "pleural effusion" were the most common radiologic findings.

Conclusion: Pulmonary involvement in systemic rheumatic diseases can occur with various radiological images even in asymptomatic patients. PFTs can be normal as well as an obstructive, restrictive or mixed pattern can be seen. Heterogeneous and combined HRCT findings can be seen in SRD patients.

Key words: Rheumatoid arthritis; systemic lupus erythematosus; sjögren's syndrome; systemic sclerosis; pulmonary involvement; high-resolution computed tomography

\section{ÖZ}

Sistemik romatizmal hastalıklarda akciğer tutulumunun, yüksek çözünürlüklü bilgisayarlı tomografi ve solunum fonksiyon testi ile değerlendirilmesi: Tek merkez deneyimi

Giriş: Bu çalışmanın amacı, sistemik romatizmal hastalıklarda (SRH) akciğer tutulumu olan hastalarda klinik, radyolojik özellikler ve solunum fonksiyon testlerini (SFT) araştırmaktır.

Materyal ve Metod: Bu çalışma retrospektif, tanımlayıcı ve tek merkezli olarak gerçekleştirildi. Ocak 2015 - Aralık 2019 yılları arasında SRH tanısı alan ve üçüncü basamak sağlık kurumu olan hastanemiz gögüs hastalıkları bölümüne başvuran/sevk edilen hastalar çalışmaya alındı. Tüm hastalar Yüksek rezolüsyonlu akciğer tomografisi (HRCT) ve SFT kullanılarak değerlendirildi.

Bulgular: Çalışmaya ortalama yaşı 62,38 \pm 12,4 yıl olan 68 hasta (15 erkek, 53 kadın) dahil edildi. Hastaların 41'inde (\%60,2) romatoid artrit (RA), 10'unda (\% 14,7) sjögren sendromu (SS), 8'inde (\% 11,7) sistemik lupus eritematozus (SLE), 6'sında (\%8,8) sistemik skleroz (SSC) ve 3'ünde $(\% 4,4)$ mix bağ dokusu hastalığı $(M B D H)$ mevcuttu. RA, SLE, MBDH hastaları genellikle semptomatik iken, SS hastaları genellikle asemptomatikti. Toplam $30(\% 44,1)$ hastada SFT normal olarak değerlendirildi. $30(\% 44,1)$ hasta asemptomatik olduğu halde ve diğer $30(\% 44,1)$ hastada normal SFT bulguları saptanmasına rağmen, HRCT ile tüm hastalarda birden fazla görüntüleme bulgusu saptandı. RA'da en sık görülen HRCT bulgusu "bronșektazi" idi, bunu "kronik fibrotik değişiklikler" ve "peribronşiyal kalınlaşma" izledi. "Kronik fibrotik değişiklikler" ve "peribronşiyal kalınlaşma", SS'deki en yaygın değişikliklerdi. Benzer şekilde, "peribronşiyal kalınlaşma" SLE' de en sık görülen HRCT bulgusuydu. SSc'de ise, "kronik fibrotik değişiklikler", interlobüler septal kalınlaşma ve plevral efüzyon en sık görülen HRCT bulgularıydı.

Sonuç: Sistemik romatizmal hastalıklarda pulmoner tutulum, asemptomatik hastalarda dahi çeşitli radyolojik görüntülerle ortaya çıkabilir. SFT normal olabileceği gibi obstruktif, restriktif veya mikst paternde olabilir. Birçok (heterojen) HRCT bulgusu görülebilir.

Anahtar kelimeler: Romatoid artrit; sistemik lupus eritematozus; sjögren sendromu; sistemik skleroz; pulmoner tutulum; yüksek çözünürlüklü bilgisayarlı tomografi

\section{INTRODUCTION}

Pulmonary involvement is an important cause of morbidity and even mortality in systemic rheumatic diseases (SRDs) (1). Previous studies have already shown that pulmonary involvement can present with different manifestations comprising the involvement of respiratory muscles, pleura, lung parenchyma, airways, interstitium and blood vessels (2-4). Respiratory complaints may be masked and the diagnosis can be challenging due to the limitation of exercise capacity because of the involvement of the musculoskeletal system (2).

In the literature, lung involvement of SRD patients were reported between \%9-48 (5-7). Accordingly, the aim of this study was to investigate the clinical and radiological features and pulmonary function tests (PFTs) in patients with the pulmonary involvement of SRDs.

\section{MATERIALS and METHODS}

This study was conducted as a retrospective, descriptive and single-center study. Patients diagnosed with systemic rheumatic disease and admitted or referred to the department of chest diseases of a tertiary hospital between January 2015 and June 2019 were enrolled. The data were obtained from the hospital automation system records and digital archives. Patients who had any inflammatory disease other than SRD, infectious disease, granulomatous diseases, malignancy or history of drug usage that could lead to any pulmonary side effects were excluded. All patients were evaluated using a high-resolution computed tomography (HRCT) and spirometry. The current study protocol was approved by the Tokat Osmangazi University Ethics Committee (Number: TOGU 83116987/621 and date: 10.10.2019). 


\section{Data Collection and Evaluation}

Demographic characteristics, duration of disease, pulmonary symptoms and PFT results were recorded, and radiological findings of each patient were interpreted by an expert radiologist and classified according to the systemic rheumatic disease type. All patients were evaluated with HRCT. HRCT is the gold standard technique to evaluate and diagnose early pulmonary involvement and subclinical lung involvement of SRD (8). The patients were also evaluated using spirometry. All PFTs were performed according to ATS / ERS guideline. Spirometry is the main pulmonary function test for the accurate and reproducible measurement of lung functions (9). If the forced vital capacity (FVC) and the forced expiratory volume in one second $\left(\mathrm{FEV}_{1}\right)$ are within $80 \%$ of the reference value, the results are considered normal. The obstruc- tive pattern was defined by a low $\mathrm{FEV}_{1} / \mathrm{FVC}$ ratio, which is defined as less than $70 \%$. A restrictive pattern on spirometry was defined as an $\mathrm{FEV}_{1} / \mathrm{FVC}$ ratio $>0.7$ and an $\mathrm{FVC}<80 \%$ of the predicted value. $\mathrm{FEV}_{1} / \mathrm{FVC}<0.7$ and $\mathrm{FVC}<80 \%$ of the predicted value is described as a "mixed" ventilatory defect (10). Example images of our patients are shown in Figure 1 and Figure 2.

\section{Statistical Analysis}

Statistical analyses were performed using SPSS version 20.0 (SPSS, Inc. Chicago, Illinois).

After checking the normal distribution with Shapiro Wilk Test and histogram graphics, the data were given as mean, standard deviation, count, and percentage. Categorical variables were compared using the Chi-Square test. Numeric variables were com-

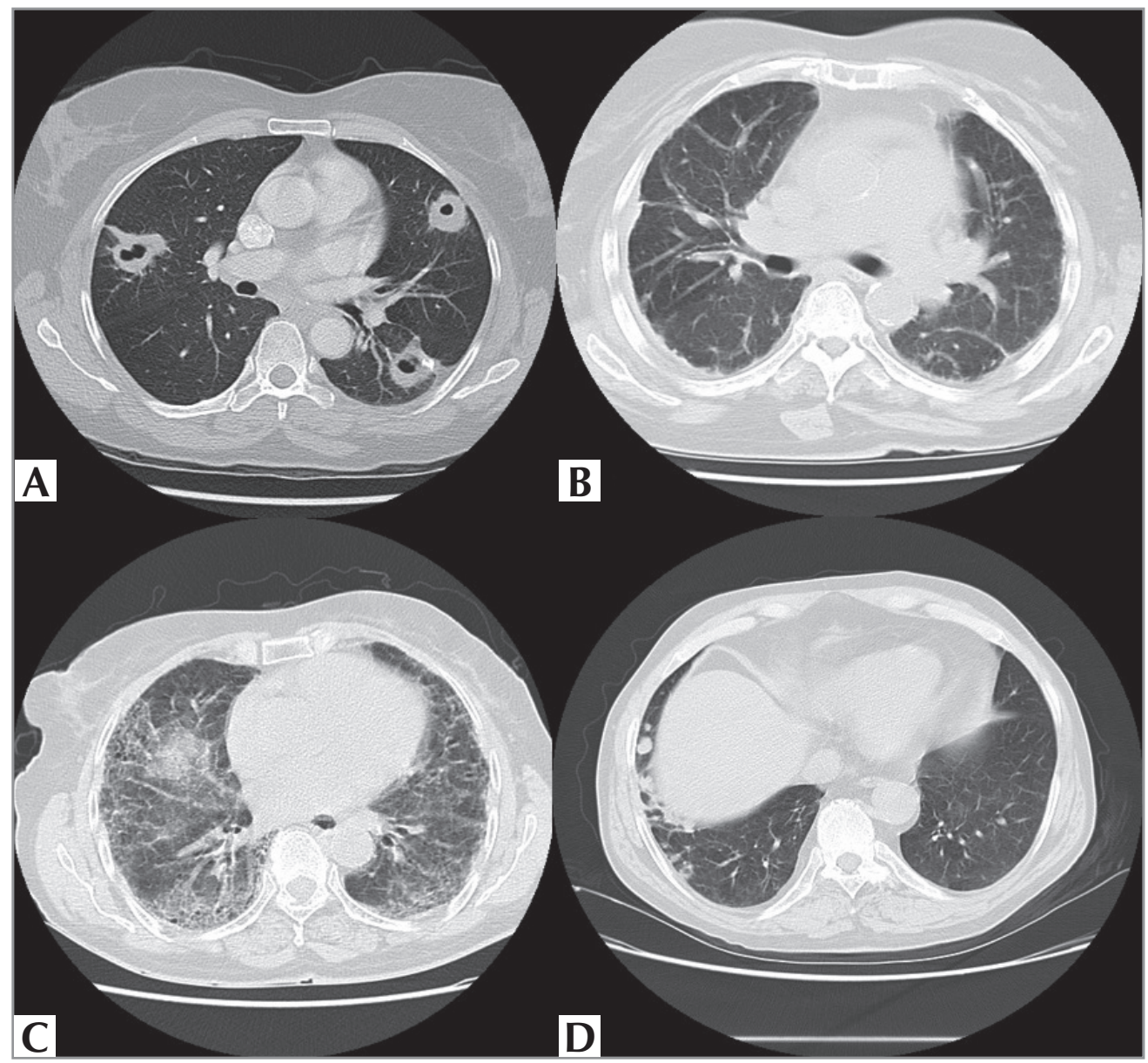

Figure 1. A. Cavitary lesions in a 56-year-old female patient with RA, B. Pleural, interlobular-septal and peribronchial thickening in a 61-year-old patient with RA, C. A 56-year-old female SSC patient with ground-glass appearance and intralobular interstitial thickening, D. A 63 -year-old male patient with RA had necrobiotic and pulmonary nodules. 


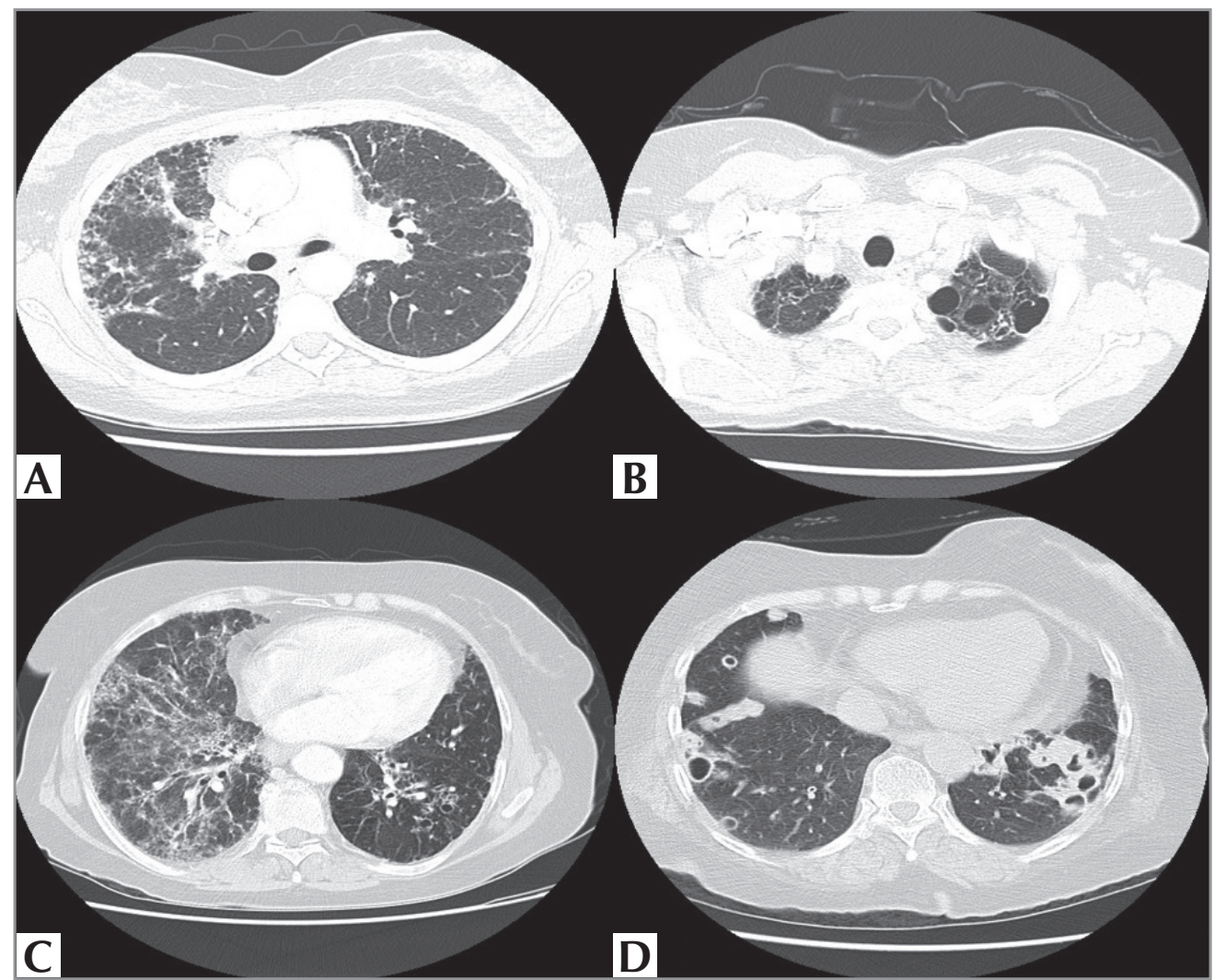

Figure 2. A. A 42-year-old female patient diagnosed as SS with a honeycomb appearance, B. Apicobullous and chronic fibrotic changes, 64-year-old female SSC patient, C. A 48-year-old female MCTD patient with bronchiectasis intralobular interstitial thickening and ground-glass appearance, D. Cavitary lesions and pulmonary nodules in a 68-year-old male RA patient.

pared using the One Way ANOVA Test. Post-hoc analyses were performed to determine the difference between the groups. A $\mathrm{P}$ value of $<0.05$ was considered statistically significant.

\section{RESULTS}

\section{Clinical and Demographical Features of Patients}

A total of 68 patients ( 15 males, 53 females) with a mean age of $62.38 \pm 12.4$ years (ranges: 39 to 82 years) were included in this study. Of the patients, 41 $(60.2 \%)$ had rheumatoid arthritis (RA), 10 (14.7\%) had Sjogren's syndrome (SS), $8(11.7 \%)$ had systemic lupus erythematosus (SLE), $6(8.8 \%)$ had systemic sclerosis (SS) and $3(4.4 \%)$ had mixed connective tissue disease (MCTD). Clinical and demographical features of the subjects are summarized in Table 1. Mean age of RA patients was higher than other systemic rheumatic disease groups $(p<0.001)$. Duration of diseases was similar between all SRDs $(p=0.13)$.

\section{Pulmonary Symptoms and Findings of PFTs}

Pulmonary symptoms and PFTs are shown in Table 2. No statistical difference was found between the groups in terms of pulmonary symptoms ( $p>0.05$ ). While RA, SLE, MCTD patients were more commonly symptomatic, most of the SS patients were asymptomatic. There was no difference in the duration of the disease between symptomatic and asymptomatic patients. (10.7 years, 12.1 years, respectively; $p=0.51$ ). According to the results of PFTs, there was no difference between the groups in forced vital capacity (FVC), forced expiratory volume in the first second $\left(\mathrm{FEV}_{1}\right)$ and $\mathrm{FEV}_{1} / \mathrm{FVC}$ ratios $(\mathrm{p}=0.72, \mathrm{p}=0.67, \mathrm{p}=0.97$, respectively). Overall, 30 (44.1\%) patients had normal PFTs. The numbers of obstructive and restrictive patterns were similar in all groups except the SLE statistically.

\section{Radiological Findings}

Although $30(\% 44.1)$ patients were asymptomatic and $30(\% 44.1)$ patients had normal PFTs, more than 
Table 1. Clinical and demographical features of the patients

\begin{tabular}{|c|c|c|c|c|c|c|}
\hline Variables & $\begin{array}{c}\text { RA } \\
(n=41)\end{array}$ & $\begin{array}{c}\text { SS } \\
(n=10)\end{array}$ & $\begin{array}{c}\text { SLE } \\
(n=8)\end{array}$ & $\begin{array}{c}\text { Systemic } \\
\text { sclerosis }(n=6)\end{array}$ & $\begin{array}{l}\text { MCTD } \\
(\mathrm{n}=3)\end{array}$ & $\mathbf{p}$ \\
\hline Age & $67.65 \pm 10.13$ & $56.90 \pm 14.53$ & $51.87 \pm 6.27$ & $57.83 \pm 12.04$ & $45.66 \pm 6.11$ & $0.001^{*}$ \\
\hline Gender & & & & & & 0.29 \\
\hline Male $(n, \%)$ & $12(29.3)$ & $0(0)$ & $2(25)$ & $1(16.6)$ & $0(0)$ & \\
\hline Female $(n, \%)$ & $29(70.7)$ & $10(100)$ & $6(75)$ & $5(83.4)$ & $3(100)$ & \\
\hline Disease duration (year) & $14.43 \pm 9.72$ & $6.20 \pm 3.16$ & $7.00 \pm 2.83$ & $9.00 \pm 6.84$ & $6.33 \pm 1.53$ & 0.13 \\
\hline \multicolumn{7}{|l|}{ Pulmonary symptom } \\
\hline Yes $(\mathrm{n}, \%)$ & $15(36.5)$ & $8(80)$ & $3(37.5)$ & $3(50)$ & $1(33.3)$ & 0.16 \\
\hline No $(n, \%)$ & $26(63.5)$ & $2(20)$ & $5(62.5)$ & $3(50)$ & $2(66.7)$ & \\
\hline
\end{tabular}

RA: Rheumatoid arthritis, SS: Sjogren's syndrome, SLE: Systemic lupus erythematosus, SSC: Systemic sclerosis, MCTD: Mixed connective tissue disease.

Table 2. Pulmonary symptoms and function test results $(n, \%)$

\begin{tabular}{|c|c|c|c|c|c|}
\hline Variables & $\begin{array}{c}\text { RA } \\
(n=41)\end{array}$ & $\begin{array}{c}\text { SS } \\
(n=10)\end{array}$ & $\begin{array}{c}\text { SLE } \\
(n=8)\end{array}$ & $\begin{array}{c}\text { SSC } \\
(n=6)\end{array}$ & $\begin{array}{r}\text { MCTD } \\
(n=3)\end{array}$ \\
\hline \multicolumn{6}{|l|}{ Symptoms } \\
\hline Asymptomatic/sypmtomatic & $15(36.5) / 26(63.5)$ & $8(80) / 2(20)$ & $3(37.5) / 5(62.5)$ & $3(50) / 3(50)$ & 1 1(33.3)/2 (66.7) \\
\hline Cough & $9(22)$ & $6(60)$ & $1(13)$ & $2(33)$ & $1(33)$ \\
\hline Dyspnea & $12(29)$ & $5(50)$ & $3(38)$ & $2(66)$ & $1(33)$ \\
\hline Sputum & $3(7)$ & $1(10)$ & $0(0)$ & $1(33)$ & $0(0)$ \\
\hline Chest pain & $4(10)$ & $2(20)$ & $1(13)$ & $2(66)$ & $0(0)$ \\
\hline Wheezing & $4(10)$ & $0(0)$ & $0(0)$ & $0(0)$ & $0(0)$ \\
\hline Hemoptysis & $1(2)$ & $0(0)$ & $0(0)$ & $0(0)$ & $0(0)$ \\
\hline \multicolumn{6}{|l|}{ PFTs } \\
\hline FVC (It) & $2.26 \pm 0.97$ & $2.24 \pm 0.69$ & $2.39 \pm 0.50$ & $2.70 \pm 0.93$ & $2.72 \pm 0.08(p=0.67)$ \\
\hline $\mathrm{FEV}_{1}(\mathrm{It} / \mathrm{sn})$ & $1.80 \pm 0.79$ & $1.83 \pm 0.61$ & $1.97 \pm 0.49$ & $2.24 \pm 0.91$ & $2.15 \pm 0.15(p=0.72)$ \\
\hline $\mathrm{FEV}_{1} / \mathrm{FVC}(\%)$ & $78.48 \pm 12.40$ & $80.30 \pm 7.52$ & $80.1 \pm 10.9$ & $80.33 \pm 11.07$ & $78.00 \pm 4.58(p=0.97)$ \\
\hline \multicolumn{6}{|l|}{ PFTs } \\
\hline Normal & $13(32)$ & $6(60)$ & $4(50)$ & $4(67)$ & $3(100)$ \\
\hline Obstructive patern & $11(27)$ & $2(20)$ & $1(13)$ & $1(17)$ & $0(0)$ \\
\hline Restrictive patern & $11(27)$ & $2(20)$ & $3(38)$ & $1(17)$ & $0(0)$ \\
\hline Mixed patern & $6(15)$ & $0(0)$ & $0(0)$ & $0(0)$ & $0(0)$ \\
\hline
\end{tabular}

one imaging finding was found in all patients with SRD according to the HRCT imaging. All imaging findings are shown in Table 3. Predominantly bronchiectasis, chronic fibrotic changes, peribronchial thickening, pulmonary nodules, pleural thickening, subsegmental linear atelectasis, ground-glass nodules/opacity, and interlobular septal thickening findings were seen in HRCT evaluation. Mosaic perfusion pattern, cavity, necrobiotic nodules and intralobular interstitial thickening were seen only RA patients. Diaphragmatic thickening/involvement was seen in only two SLE patients. Pleural effusion was seen only two SSC patients. Comparisons of radiological findings of symptomatic and asymptomatic patients are shown in Table 4.

\section{DISCUSSION}

This study aimed to explore the clinical and radiological features of pulmonary involvement in SRDs, using the HRCT and PFTs. There are three main findings according to our results. First, pulmonary involvement can present with various symptoms and radiological images, event in asymptomatic patients. PFTs can be normal as well as an obstructive, restric- 
Pulmonary involvement in systemic rheumatic diseases

Table 3. Radiological findings of high resolution computed tomography $(\mathrm{n}, \%)$

\begin{tabular}{|c|c|c|c|c|c|}
\hline Findings & RA $(n=41)$ & SS $(n=10)$ & $\operatorname{SLE}(n=8)$ & $\operatorname{SSC}(n=6)$ & MCTD $(n=3)$ \\
\hline Bronchiectasis & $27(65.8)$ & $2(20)$ & $1(12.5)$ & 1 (16.6) & $2(66.6)$ \\
\hline Chronic fibrotic changes & $22(53.6)$ & $4(40)$ & $2(25)$ & $2(33.3)$ & $0(0)$ \\
\hline Peribronchial thickening & $20(48.7)$ & $4(40)$ & $5(62.5)$ & $1(16.6)$ & $2(66.6)$ \\
\hline Pulmonary nodules & $18(43.9)$ & $2(20)$ & $2(25)$ & $1(16.6)$ & $1(33.3)$ \\
\hline Pleural thickening & $14(34.1)$ & $3(30)$ & $1(12.5)$ & $1(16.6)$ & $1(33.3)$ \\
\hline Subsegmentary linear atelectasis & $13(31.7)$ & $2(20)$ & $4(50)$ & $1(16.6)$ & $1(33.3)$ \\
\hline Ground-glass nodules/opacity & $12(29.2)$ & $2(20)$ & $2(25)$ & $1(16.6)$ & $1(33.3)$ \\
\hline Interlobular septal thickening & $11(26.8)$ & $3(30)$ & $0(0)$ & $2(33.3)$ & $1(33.3)$ \\
\hline Mosaic perfusion pattern & $9(21.9)$ & $0(0)$ & $0(0)$ & $0(0)$ & $0(0)$ \\
\hline Pulmonary vascular enlargement & $9(21.9)$ & $1(10)$ & $1(12.5)$ & $0(0)$ & $0(0)$ \\
\hline Ground-glass appearance & $9(21.9)$ & $3(30)$ & $2(25)$ & $0(0)$ & $0(0)$ \\
\hline Paratracheal/subcarinal/prevascular LAP & $8(19.5)$ & $2(20)$ & $1(12.5)$ & $0(0)$ & $0(0)$ \\
\hline Honeycombing & $6(14.6)$ & $1(10)$ & $0(0)$ & $1(16.6)$ & $1(33.3)$ \\
\hline Mediastenal/hilar LAP & $5(12.1)$ & $2(20)$ & $2(25)$ & $0(0)$ & $0(0)$ \\
\hline Cavity & $5(12.1)$ & $0(0)$ & $0(0)$ & $0(0)$ & $0(0)$ \\
\hline Pleural effusion & $3(7.3)$ & $0(0)$ & $0(0)$ & $2(33.3)$ & $0(0)$ \\
\hline Necrobiotic nodules & $3(7.3)$ & $0(0)$ & $0(0)$ & $0(0)$ & $0(0)$ \\
\hline Apicobullous changes & $2(4.8)$ & $0(0)$ & $0(0)$ & $1(16.6)$ & $0(0)$ \\
\hline Intralobular interstitial thickening & $2(4.8)$ & $0(0)$ & $0(0)$ & $0(0)$ & $0(0)$ \\
\hline Patchy infiltrate & $2(4.8)$ & $2(20)$ & $0(0)$ & $0(0)$ & $0(0)$ \\
\hline Reticulonodular appearance & $1(2.4)$ & $2(20)$ & $0(0)$ & $2(33.3)$ & $0(0)$ \\
\hline Diaphragmatic thickening/involvement & $0(0)$ & $0(0)$ & $2(25)$ & $0(0)$ & $0(0)$ \\
\hline
\end{tabular}

RA: Rheumatoid arthritis, SS: Sjogren's syndrome, SLE: Systemic lupus erythematosus, SSC: Systemic sclerosis, MCTD: Mixed connective tissue disease, LAP: Lymphadenopathy.

Table 4. Comparisons of radiological findings of symptomatic and asymptomatic patients (n, \%)

\section{Findings}

Bronchiectasis

Chronic fibrotic changes

Peribronchial thickening

Pulmonary nodules

Pleural thickening

Subsegmentary linear atelectasis

Ground-glass nodules/opacity

Interlobular septal thickening

Mosaic perfusion pattern

Pulmonary vascular enlargement

Paratracheal/subcarinal/prevascular LAP

Honeycombing

Mediastenal/hilar LAP

Cavity

Pleural effusion

Necrobiotic nodules

Apicobullous changes

Intralobular interstitial thickening

Patchy infiltrate

Reticulonodular appearance

Diaphragmatic thickening/involvement

\section{Symptomatic $(n=30)$}

$17(57)$

$13(43)$

16(53)

$7(23)$

10(33)

$8(27)$

6(20)

11(37)

2(7)

6(20)

$4(13)$

6 (20)

4(13)

1(3)

3(10)

$0(0)$

$0(0)$

1(3)

3 (10)

2(7)

$0(0)$
Asymptomatic $(\mathrm{n}=38)$

18(47)

17(45)

$16(42)$

17 (45)

$10(26)$

13(34)

12(32)

6(16)

$1(3)$

$5(13)$

$7(18)$

3(8)

$5(13)$

$4(11)$

2(5)

$3(8)$

$3(8)$

$1(3)$

1 (3)

$3(8)$

2 (5)

RA: Rheumatoid arthritis, SS: Sjogren's syndrome, SLE: Systemic lupus erythematosus, SSC: Systemic sclerosis, MCTD: Mixed connective tissue disease, LAP: Lymphadenopathy. 
tive or mixed pattern can be seen. Third, heterogeneous and multiple HRCT findings can be seen in SRD patients. In our study, bronchiectasis was the most common HRCT finding in RA, followed by chronic fibrotic changes and peribronchial thickening. Chronic fibrotic changes and peribronchial thickening are the most common changes in SS. Similarly, peribronchial thickening is the most common HRCT finding in SLE. As for the SSc, chronic fibrotic changes, interlobular septal thickening, and pleural effusion are the most common HRCT findings.

Pulmonary findings and involvements in SRD have been previously studied in different studies. Vitali et al. have highlighted a high prevalence of asymptomatic lung involvement among patients with different SRD (11). Only $17.8 \%$ of the patients were symptomatic and mild dyspnea on exercise was the most common symptom in SRDs. Moreover, Renzoni et al. have compared 17 patients who had idiopathic pulmonary fibrosis (LIPF) with pulmonary fibrosis associated with connective tissue disorders (PFCTD) whereby no significant difference was determined between two groups in terms of PFT parameters (12). However, patients in the PFCTD group were more asymptomatic. In our study, more than half of the patients $(55.8 \%)$ were asymptomatic, and $30(44.1 \%)$ patients had normal PFTs. The most common PFT abnormalities were the obstructive $(22 \%)$ and restrictive patterns (25\%). Dyspnea (33.2\%) and cough (27.9\%) were common symptoms.

In the literature, there are reports of different rates of lung involvement in patients with SRD. Fujii et al. have reported a $50 \%$ rate of lung involvement using HRCT (13). In another study evaluating 20 RA, 20 AS and 20 healthy individuals, the authors have stated that $70 \%$ of RA and $50 \%$ of AS patients had abnormal HRCT findings and the most common HRCT abnormalities are interstitial lung disease, bronchiectasis and pleural disease (14). It is not clear whether bronchiectasis represents with the inflammatory disease being directly responsible for the bronchial damage, or results from a preexisting pulmonary complication such as alveolitis or bronchiolitis obliterans organizing pneumonia (15). Bronchiectasis was the most common radiological finding in our examinations.

While early-onset RA patients have common groundglass opacities, many studies have shown that HRCT has a more reticulonodular and honeycomb appearance than ground-glass opacities in RA patients (14,
16-17). HRCT findings in SS are ground-glass opacities, nodules, and thin-walled cysts (18). In the study of Matsuyama et al. (19), centrilobular thickening and lymphoproliferative disorders have been observed to be characteristic of SS patients. Honeycomb appearance and pulmonary fibrosis are reported to be relatively rare features of SS (20). Fenlon et al. have found interstitial lung disease findings in HRCT in one-third of SLE patients. Only two of the 34 patients included in the study had a honeycomb appearance (21). In addition, Bankier et al. have found pulmonary fibrosis in one-third of 45 asymptomatic SLE patients with HRCT (22). More importantly, in both publications, interlobular septal thickening was the most common interstitial change. Further studies have not been conducted on the HRCT features of MCTD. In a study involving 41 patients, the appearance of ground glass in all patients, nodules and reticular opacities are also commonly seen in predominantly peripheral lower zones and honeycomb appearance is less common (23). In our study, we found more than one HRCT findings in each patient in systemic rheumatic disease groups. According to our observations, the most common HRCT findings in RA were bronchiectasis, chronic fibrotic changes and peribronchial thickening. In SS patients, the most common HRCT findings were chronic fibrotic changes and peribronchial thickening, the latter is also the most common in SLE. Chronic fibrotic changes, interlobular septal thickening, and pleural effusion are the most common HRCT findings in SSc patients.

\section{Limitations}

The retrospective study design is the main limitation. Since the study had a retrospective design, diffusion capacity of the patients could not be measured. Sample size of the study is acceptable when compared with several previous studies. However, subgroup analysis could not performed because the number of patients was too small to perform statistical analysis.

\section{CONCLUSION}

Pulmonary involvement in SRDs can present with various symptoms and radiological images, and events in asymptomatic patients. PFTs can be normal as well as an obstructive, restrictive or mixed pattern can be seen. In conclusion, proper diagnosis and management of pulmonary involvement are crucial in SRD patients. 
Ethical Committee Approval: This study was obtained from Tokat Gaziosmanpaşa University Ethical Commitee (Decision No: 83116987-GRI Date: 24.09.2019)

\section{CONFLICT of INTEREST}

The authors of this meta-analysis declare that they have no conflict of interest.

\section{AUTHORSHIP CONTRIBUTIONS}

Concept/Design: ACP, TE

Analysis/Interpretation: ACP, HIK, HIY

Data Acqusition: ACP, HiY, RYÇ

Writing: ACP

Clinical Revision: ACP, TE, HiK

Final Approval: ACP, HIY, HIK, RYÇ, TE

\section{REFERENCES}

1. Dumas G, Géri G, Montlahuc C, Chemam S, Dangers L, Pichereau C, et al. Outcomes in critically ill patients with systemic rheumatic disease. Chest 2015; 148(4): 927-35.

2. Dellaripa PF, Fischer A, Flaherty KR. Pulmonary Manifestations of Rheumatic Disease: A Comprehensive Guide. New York: Springer; 2014.

3. Ha YJ, Lee YJ, Kang EH. Lung involvements in rheumatic diseases: update on the epidemiology, pathogenesis, clinical features, and treatment. Biomed Res Int 2018; 6930297.

4. Doyle TJ, Dellaripa PF. Lung manifestations in the rheumatic diseases. Chest 2017; 152(6): 1283-95

5. Karazincir S, Akoğlu S, Güler H, Balci A, Babayiğit C, Ĕgilmez $E$. The evaluation of early pulmonary involvement with high resolution computerized tomography in asymptomatic and non-smoker patients with rheumatoid arthritis. Tuberk Toraks 2009; 57(1): 14-21.

6. Perelas A, Arrossi AV, Highland KB. Pulmonary manifestations of systemic sclerosis and mixed connective tissue disease. Clin Chest Med 2019; 40(3): 501-18.

7. Natalini JG, Johr C, Kreider M. Pulmonary involvement in Sjögren syndrome. Clin Chest Med 2019; 40(3): 531-44.

8. Gutierrez $M$, Salaffi $F$, Carotti $M$, Tardella M, Pineda $C$, Bertolazzi C, et al. Utility of a simplified ultrasound assessment to assess interstitial pulmonary fibrosis in connective tissue disorders: preliminary results. Arthritis Res Ther 2011; 13(4): R134

9. García-Río F, Calle M, Burgos F, Casan P, Del Campo F, Galdiz JB, et al. Spirometry. Arch Bronconeumol 2013; 49(9): 388-401.

10. Ulubay G, Dilektaşı AG, Börekçi Ş, Yıldız Ö, Kıyan E, Gemicioglu B, et al.Turkish Thoracic Society Consensus Report: Interpretation of Spirometry. Turk Thorac I 2019; 20(1): 69-89.
11. Vitali C, Viegi G, Tassoni S, Tavoni A, Paoletti P, Bibolotti E, et al. Lung function abnormalities in different connective tissue diseases. Clin Rheumatol 1986; 5(2): 181-8.

12. Renzoni E, Rottoli P, Coviello G, Perari MG, Galeazzi M, Vagliasindi $M$. Clinical, laboratory and radiological findings in pulmonary fibrosis with and without connective tissue disease. Clin Rheumatol 1997; 16(6): 570-7.

13. Fujii $M$, Adachi S, Shimizu T, Hirota S, Sako M, Kono $M$. Interstitial lung disease in rheumatoid arthritis: assessment with high-resolution computed tomography. I Thorac Imaging 1993; 8(1): 54-62.

14. Ayhan-Ardic FF, Oken O, Yorgancioglu ZR, Ustun N, Gokharman FD. Pulmonary involvement in lifelong nonsmoking patients with rheumatoid arthritis and ankylosing spondylitis without respiratory symptoms. Clin Rheumatol 2006; 25(2): 213-8.

15. Lieberman-Maran L, Orzano IM, Passero MA, Lally EV. Bronchiectasis in rheumatoid arthritis: report of four cases and a review of the literature implications for management with biologic response modifiers. Semin Arthritis Rheum 2006; 35(6): 379-87.

16. Akira M, Sakatani M, Hara H. Thin-section CT findings in rheumatoid arthritis-associated lung disease: $C T$ patterns and their courses. J Comput Assist Tomogr 1999; 23(6): 941-8.

17. Zrour SH, Touzi M, Bejia I, Golli M, Rouatbi N, Sakly N, et al. Correlations between high-resolution computed tomography of the chest and clinical function in patients with rheumatoid arthritis: prospective study in 75 patients. Joint Bone Spine 2005; 72(1): 41-7.

18. Devaraj A, Wells AU, Hansell DM. Computed tomographic imaging in connective tissue diseases. Semin Respir Crit Care Med 2007; 28(4): 389-97.

19. Matsuyama N, Ashizawa K, Okimoto T, Kadota J, Amano H, Hayashi K. Pulmonary lesions associated with Sjögren's syndrome: radiographic and $\mathrm{CT}$ findings. $\mathrm{Br} /$ Radiol 2003;76: 880-4.

20. 20. Desai SR, Veeraraghavan S, Hansell DM, Nikolakopolou A, Goh NSL, Nicholson AG, et al. CT features of lung disease in patients with systemic sclerosis: comparison with idiopathic pulmonary fibrosis and nonspecific interstitial pneumonia. Radiology 2004; 232(2): 560-7.

21. Fenlon HM, Doran M, Sant SM, Breatnach E. Highresolution $C T$ in systemic lupus erythematosus. AJR Am J Roentgenol 1996; 166(2): 301-7.

22. Bankier AA, Kiener HP, Wiesmayr MN et al.Discrete lung involvement in systemic lupus erythematosus: $C T$ assessment. Radiology 1995; 196(3): 835-40.

23. Prakash UB. Respiratory complications in mixed connective tissue disease. Clin Chest Med 1998; 19(4): 733-46. 